九州大学学術情報リポジトリ

Kyushu University Institutional Repository

\title{
Performance of Male Bali Cattle Raised in the Marginal Land with Three Strata Forage System in Different Seasons
}

Hasan, Syamsudd in

Animal Nutrion Department, Animal Husbandry Faculty, Hasanuddin University

Masuda, Yasuhira

Shimojo, Masataka

Natasir, Asmuddin

Animal Nutrion Department, Animal Husbandry Faculty, Hasanuddin University

https://doi.org/10.5109/4629

出版情報: 九州大学大学院農学研究院紀要. 50 (1)，pp. 125-128，2005-02-01. Faculty of Agriculture, Kyushu University

バージョン :

権利関係 : 


\title{
Performance of Male Bali Cattle Raised in the Marginal Land with Three Strata Forage System in Different Seasons
}

\author{
Syamsuddin HASAN ${ }^{1 *}$, Yasuhisa MASUDA, Masataka SHIMOJO \\ and Asmuddin NATSIR
}

\author{
Laboratory of Animal Feed Science, Division of Animal Science, Department of \\ Animal and Marine Bioresource Sciences, Faculty of Agriculture, \\ Kyushu University, Fukuoka 812-8581, Japan \\ (Received October 30, 2004 and accepted November 11, 2004)
}

\begin{abstract}
This study was conducted to evaluate the performance of male Bali Cattle raised in marginal land planted with three strata forage system (TSFS) in different seasons. A-3.2 ha of marginal land was divided into eight plots (each plot was $40 \mathrm{~m} \times 100 \mathrm{~m}$ ), then four plots were planted with the TSFS and other four plots were planted with native grasses (Control: C). Eight head of male Bali cattle (average body weight $150 \mathrm{~kg}$ ) grazed continuously in the experimental land (1 cattle/plot). The experiment was carried out for three consecutive years (1992-1995). Dry matter intake $(D M I)$, average daily gain $(A D G)$, efficiency of feed intake $(E F I)$, and rumen $\mathrm{NH}_{3}\left(R-\mathrm{NH}_{3}\right)$ of the cattle grazing in the TSFS land were $6.292 \mathrm{~kg} / \mathrm{head} / \mathrm{day}, 0.365 \mathrm{~kg} / \mathrm{head} /$ day, $18.508 \%$, and $25.670 \mathrm{mg} / 100 \mathrm{ml}$, respectively. $D M I, A D G, E F I$ and $R-\mathrm{NH}_{3}$ for the $\mathrm{C}$ were $3.950 \mathrm{~kg} / \mathrm{head} /$ day, $0.170 \mathrm{~kg} / \mathrm{head} /$ day, $23.825 \%$, and $19.025 \mathrm{mg} / 100 \mathrm{ml}$, respectively. Comparing between wet and dry seasons showed 5.533 versus $4.708 \mathrm{~kg} /$ head/day for $D M I, 0.288$ versus $0.247 \mathrm{~kg} / \mathrm{head} /$ day for $A D G$ and 19.348 versus $23.985 \%$ for $E F I$, but $R-\mathrm{NH}_{\text {: }}$ was not different ( 22.162 versus $22.533 \mathrm{mg} / 100 \mathrm{ml}$ ). In conclusion, the performance of Bali male cattle grazing in the marginal land with TSFS system was better than that of cattle raised in the land of native grasses.
\end{abstract}

\section{INTRODUCTION}

Most Bali cattle, the original cattle in Indonesia, are raised traditionally by the farmers using the main feed source of natural grasses and agricultural by-products. In South Sulawesi, $95 \%$ of these cattle were raised in the village area (Katoe, 1984). In recent years, the productivity of Bali Cattle has tended to decrease. This is closely related to the availability of forages. The number and the area of the grazing land, the main forage source for the cattle, have continued to decrease due to the increment of land utilization by other fields, such as plantation, industry and so on.

As optimized utilization of the critical/marginal land, the alternative is to plant the marginal/critical land area with three strata forage system (TSFS). The TSFS reduces soil erosion, increases soil fertility and soil organic matter, and improves physical structure of the soil organic matter, and improves physical structure of the soil (Nitis et al., 1989). Also it helps soil recovery, prevents soil destruction and fertility of the soil

\footnotetext{
1 Animal Nutrition Department, Animal Husbandry Faculty, Hasanuddin University, Ujung Pandang, Indonesia (90245)

* Corresponding author (E-mail: hasan_syam@hotmail.com)
} 
(Soerodjotanojo, 1983; Seta, 1987). In addition, the TSFS makes the forage, in both quantity and quality, available along the year.

The purpose of this study was to evaluate the performance of male Bali Cattle grazing in the marginal land planted with the TSFS in different seasons.

\section{MATERIALS AND METHODS}

This research was conducted on a 3.2 ha marginal land. The land was divided into four blocks, then each block was divided into two units, each unit was $40 \mathrm{~m} \times 100 \mathrm{~m}$. Then, one unit in each block was planted with animal feed plants with the TSFS and the other was planted with native grasses (Control: C), therefore, the total of experimental units were 8, four unit for the TSFS and four unit for the C, respectively. The TSFS was arranged as follows. The outset of the unit was planted with fodder trees, Leucaena leucocephala and Gliricidia maculata, with $0.5 \mathrm{~m}$ spacing between those two plants for stratum 3. The inner zone of the unit, five meters from the fodder trees, was planted with buffelgrass (Cenchrus ciliaris) and siratro (Macroptilium atropurpureum) for stratum 2, and the center of the unit was planted with setaria (Setaria sphacelata) and centro (Centrosema pubescens) for stratum 1 (Fig. 1).

This research was conducted for three years, and each year was divided into periods, namely the period of dry season and that of wet season. The total of experimental periods were six (P1, P2, P3, P4, P5 and P6). One year following planting of the TSFS, 8 head of male Bali cattle, average body weight $150 \mathrm{~kg}$, grazed on the experimental land (1 cattle/unit). Water was always available at the experimental land, while minerals for

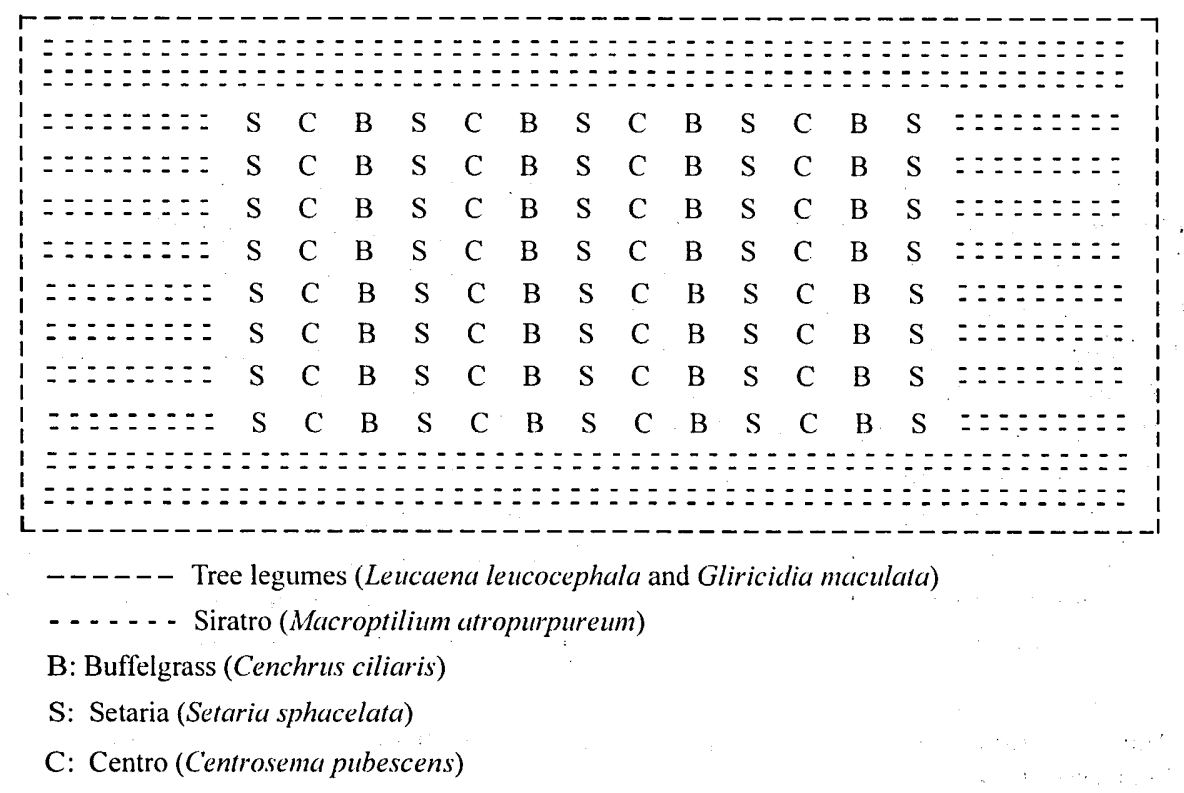

Fig. 1. A scheme of three strata forage system in each unit of the experimental marginal land. 
that $D M I$ (kg/head/day), $A D G\left(\mathrm{~kg} / \mathrm{head} /\right.$ day), $E F I(\%)$ and $R-\mathrm{NH}_{3}(\mathrm{mg} / 100 \mathrm{ml})$ of the cattle grazing in the TSFS were higher or improved than those of cattle grazing in the $\mathrm{C}$, namely 6.380 versus 3.950 for $D M I, 0.365$ versus 0.170 for $A D G, 18.508$ versus 23.825 for $E F I$, and 25.670 versus 19.025 for $R-\mathrm{NH}_{3}$, respectively.

The improved performance of the cattle raised in the TSFS land was highly related to the better condition of vegetation in the TSFS compared with the C. In addition, forages in the TSFS was a mixed planting of grasses and legumes, therefore, the quality of diets originated from the TSFS land was higher than that from the C. As a consequence, a better performance was shown by the cattle in the TSFS than the cattle in the C.

Analysis also indicated that the performance of cattle in the wet season was better than that of cattle in the dry season; 5.625 versus 4.705 for $D M I$ ( $\mathrm{kg} / \mathrm{head} /$ day), 0.305 versus 0.230 for $A D G$ (kg/head/day), 19.348 versus 22.985 for $E F I$ (\%), however, $R-\mathrm{NH}_{3}$ was not different between the TSFS and the C. This phenomenon could be understood because the growth of forages was better in the wet season than in the dry season, resulting in that more amounts of feed with higher quality were available in the wet season compared with the dry season.

In general $A D G$ of Bali cattle in the wet season was higher than that in the dry season, but $A D G$ of the cattle in the TSFS in dry season was still higher than that in the $\mathrm{C}$ in the wet season. This indicates that the TSFS can maintain the availability of forages in both quality and quantity along the year.

\section{CONCLUSIONS}

The performance of the Bali male cattle grazing in the TSFS land was higher than that of the cattle raised in the $\mathrm{C}$ land not only in the wet season but also in the dry season.

\section{ACKNOWLEDGEMENTS}

The author would like to thank the DP4M Depdikbud for funding this research through Hibah Bersaing Project I.

\section{REFERENCES}

Katoe, M. Z. 1988 Participation of the PT. Berdikari United Livestock in Development of Village Husbandry in South Sulawesi. Seminar Proceeding, Ujung Pandang

't Mannetje, L. 1978 Measuring of vegetation and animal production of grassland. Bull 52. Commonwealth Bureau of Pasture and Field Crops, England

Nitis, I., K. Lana, M. Suarna, W. Sukanten, S. Putra and W. Arga 1989 Three strata forage system for cattle feeds and feeding in dry land farming area in Bali. Fac. Animal Husbandry, Udayana University, Bali

Reksohadiprodjo, S. 1985 Production of Tropical Forage. BPFE, Yogyakarta

SAS 1985 SAS User's Guide : Statistic. SAS Ins., Inc. Cary, NC

Seta, A. K. 1987 Conservation of Soil and Water Resources. Kalam Mulya, Jakarta

Soerodjotanojo, S. 1983 Guidance for Lamtoro gung plantation. PN Balai Pustaka, Jakarta 